\title{
Further Apprenticeship: šamallû to mašmaššu șehru
}

This chapter discusses the limited material that exists from Kișir-Aššur's "apprentice" šamallû, "junior apprentice exorcist” šamallû mašmaššu șehru and "junior exorcist" mašmaššu șehru phases to provide an overview of what is currently known about these intermediate phases of his training. Furthermore, a text related to calming an infant or a child from Kișir-Aššur's šamallû mašmaššu șehru-phase is used to suggest that he acquired healing competences related to children. This chapter therefore discusses KișirAššur's possible involvement in healing infants and considers the general theories on infant and child healing in relation to Kiṣir-Aššur's previous tablets. Texts from Kișir-Aššur's nephew, Kișir-Nabû, are used to contextualize and discuss Kiṣir-Aššur's manuscripts from his šamallû mašmaššu șehru-and mašmaššu șehru-phases. Furthermore, Kiṣir-Aššur's tablets labelled as u'iltus are also discussed in general.

Additionally, this chapter examines Kișir-Aššur's use of the phrase "(he) whose trust is Nabû" (ša Nabû tuklasssu) in colophons from his šamallû șehru and šamallû mašmaššu șehru phases, as well as on tablets without titles. This facilitates the distribution of a few tablets without titles onto Kișir-Aššur's apprentice career phases.

After Kișir-Aššur's relatively well-attested šamallû șehru-phase, Kișir-Aššur became a šamallûu "apprentice" (Maul 2010: 208 and note 67). The phase is unfortunately only attested by two texts, of which one is unpublished. What follows presents the relevant tablets and their content in order to facilitate a cautious discussion of the manuscripts in relation to Kiṣir-Aššur's career. The texts are listed in the table below.

$K A L 10$ no. 4 is a large tablet with an introductory diagnostic statement as well as a multitude of incantations and brief instructions directed at releasing a "Curse" (rev. 46: [KA.INI]M.MA 「NAM ?'É[RIM.BÚR]. 「RU?.DA.KÁM). 
Text

\section{Content}

Format and

designation

Portrait; țupu

a Kiṣir-Aššur's title is preserved in rev. 19 as lúŠAB.T[UR]. Seeing as the line is not tightly written, there is no reason to assume further signs should be reconstructed, although the side of the tablet is broken and it could technically have held lúšAB.T[UR TUR].

The colophon provides the writing lúšam-lu- ${ }^{\top} \breve{u}^{1}$ for the title šamallûu (rev. 48). ${ }^{1}$ The text ends with a curse: "[He who] carries off th[is tablet], may the gods of heaven and earth ta[ke away] his eye(sight)". ${ }^{2}$

The unpublished text $\mathrm{N}_{4}$ no. 175 outlines parts of the ritual known as bit mèseri "the house of confinement" (Borger 1974; see also ibid. 1994). As shown in the detailed discussion of this ritual in Section 6.3.2, bit mèseri made use of a number of figurines and drawings alongside incantations and ritual actions, in order to rid a patient and his house of demons (Seidl and Sallaberger 2005-06: 67; Wiggermann 1992: 106-13; Meier 1941-44: 140). A line in N4 no. 175 indicates that the ritual was somehow connected to the ritual action of "rubbing" (muššu'u, rev. 6; see also Böck 2007; ibid. 2003). In the colophon, an erased line

1 Such a spelling is not attested in Kișir-Aššur's other tablets with titles composed of the word šamallû (șehru/mašmaššu șehru). However, the abbreviated form is attested elsewhere in Assur and Huzirina (e.g., Fadhil 2012: 55; Hunger 1968: 10).

$2 K A L 10$ no. 4 rev. 51: [ša țuppa šu]-`a'-tú TÙM DINGIR 'ša-me-e q qaq-qa-ri IGIII-šú lit-[ba-lu]. Note also the writing IGI.KÁR in rev. 48 for bari "checked", which is otherwise only attested in Kișir-Aššur's N4 no. 224 from an uncertain phase of his career. 
between rev. 18 and 19 still has ŠID-nu legible, and the line may once have held additional instructions.

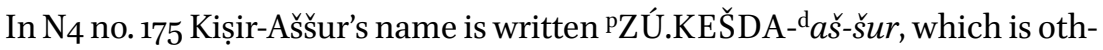
erwise only attested in BAM 121 from an uncertain phase (see Sections 5.4 and 7.2.1). Furthermore, he copied his father Nabû-bēssunu's title mašmašbit Aššur with a Babylonian form of the sign É, possibly indicating that Kiṣir-Aššur was trained in Babylonian sign forms. ${ }^{3}$ The tablet was also described as "quickly extracted for his (own) 'reading". ${ }^{4}$ In this context, the word tämartu can be translated "viewing, reading" ( $C A D$ T: 111-114; $A H w$ : 1313), and it must be considered a technical term related to knowledge acquisition, although the exact nuances are not clear (see Robson 2019: 124 and note 117; ibid. 2014: 152; Geller 2010: 134, 136-138). However, N4 no. 175 is the only tablet among Kișir-Aššur's manuscripts with this phrase (cf. ACh Supp. 224 in Section 7.6). By comparison, Kișir-Nabû copied at least three tablets "for his (own) 'reading", and these are all commentaries. ${ }^{5}$ The colophon of $\mathrm{N}_{4}$ no. 175 ends with a warning to the reader: "He who carries (the tablet) off, wherever he lifts his hands to (praise) Nabû, let him (i.e. Nabû) not hear his prayer, [he who fea]rs Nabû and Marduk shall not erase my written name!".6

Both Kișir-Aššur's šamallû-phase tablets contain portions of two types of rituals, which were integral to the äšipu's profession according to the EM (Geller 2018b; ibid. 2000). The manuscripts indicate that Kișir-Aššur as a šamallû focused on acquiring further ritual means to treat a so-called "Curse", possibly as a cause of illness, as well as gaining an insight into how the important demarcation ritual bit méseri was performed. The latter observation is supported by the addition of the phrase "for his 'reading" in the colophon. Overviews of rituals slightly similar in form to $\mathrm{N}_{4}$ no. 175 , although with different aims, are otherwise found during Kișir-Aššur's mašmaššu-phase (KAR 298 ) and on a tablet without a title (KAL 10 no. 1). Presumably, Kiṣir-Aššur's two šamallû tablets enabled Kișir-Aššur to apply ritual treatments towards "Curse" as a cause of illness and aid in preparing or performing the bìt mēseri ritual.

3 The É in Nabû-bēssunu's title mašmaš büt Aššur was also written with a Babylonian form of the sign in $\mathrm{N}_{4}$ no. 241, copied on behalf of Kiṣir-Aššur as a šamallu șehru (Section 3.7.3). Note also the Babylonian form of the sign LÚ in the colophon of BAM 28 (see Ch. 8 note 18).

4 Rev. 22: ana IGI.DU $U_{8}$ A-šú h̆a-an-țiš is-su-ḩa.

$5 A f O 12$ pl. 13-14 (ana IGI.DU $8 . A-s ̌ u ́)$, a commentary on Tummu bìtu and Šurpu tablet 2 (CCP 2.1.C); N4 no. 163 (ana IGI.LÁ-šú), a commentary on Marduk's Address to the Demons (CCP 2.2.1.A.a); N4 no. 220 (ana a-ma-ri-šú), a commentary on Tummu bìtu and Maqlû tablets 1-2 (CCP 2.1.A). Kișir-Nabû also copied three texts with related terminology: $B A M 5^{2}$ (malsūtu), BAM 106 (malsūtu) and Iraq 62 no. 35 (mašaltu, see Frahm 2011a: 268-270; CCP 2.2.1.A.b).

6 Rev. 23-25: [š]á IR e-ma a-na ${ }^{\mathrm{d}} \mathrm{AG}$ ŠU UII-su ÍL-ú ${ }^{24}$ [s]u-up-pi-šu a-a i-šam-mé ${ }^{25}$ [MU]D d AG u ${ }^{\mathrm{d} A M A R . U T U}$ MU SAR la ta-pa-šit. 
After the "apprentice"-phase, Kișir-Aššur became a "junior apprentice exorcist". Previous research has not been able to differentiate these phases beyond the change in titles. ${ }^{7}$ Due to the meagre šamallû evidence presented above, doing so remains difficult. Regardless, it is still possible to present some observations in relation to the available evidence. Kișir-Aššur only copied three preserved texts during his šamallû mašmaššu șehru-phase, and these are presented in the table below:

TABLE 7 Texts assigned to Kiṣir-Aššur's šamallû mašmaššu șehru-phase

\begin{tabular}{|c|c|c|}
\hline Text & Content & $\begin{array}{l}\text { Format and } \\
\text { designation }\end{array}$ \\
\hline$L K A 89+L K A 90$ & 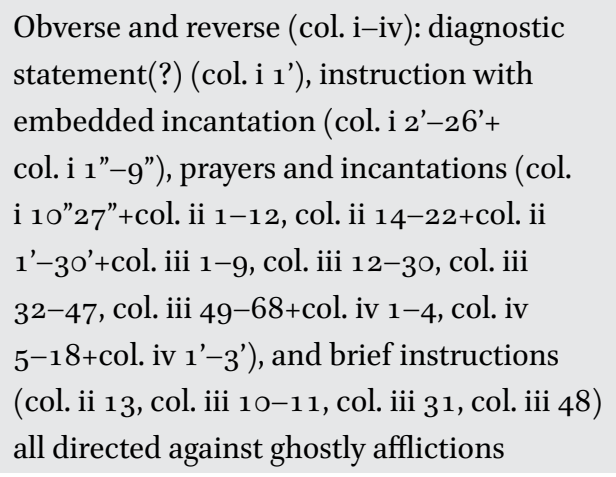 & $\begin{array}{l}\text { Two-columned; } \\
\text { țppu(?) }\end{array}$ \\
\hline$L K A 141$ & $\begin{array}{l}\text { Obverse and reverse: prayers (obv. } 1-3 \text {, } \\
\left.17-20+[\ldots]) \text {, an incantation (rev. } 1^{\prime}\right) \text {, and } \\
\text { ritual instructions (obv. } 4^{-1} 5 \text {, rev. } 3^{\prime}-8^{\prime} \text { ) for } \\
\text { reconciling a man with his god. }\end{array}$ & Portrait(?); tuppu \\
\hline $\mathrm{N}_{4}$ no. $24^{\mathrm{a}}$ & $\begin{array}{l}\text { Obverse and reverse: incantation revolving } \\
\text { around Lamaštu (obv. 1-rev. 15) with a } \\
\text { rubric stating it was designed to "calm a } \\
\text { child" (rev. 16: LÚ.TUR.HUN.GÁ) }\end{array}$ & $\begin{array}{l}\text { Landscape; } \\
\text { IM.GÍD.DA }\end{array}$ \\
\hline
\end{tabular}

a According to the most recent copy by Farber (1989: pl. 13), Kișir-Aššur was mašmaššu șehru (MAŠ.MAŠ TUR) when he copied this text. However, recent collations by Daniel Schwemer (personal communication) revealed the writing ŠÁMAN.LÁ in a smaller script underneath his title. This addition indicates Kișir-Aššur was šamallû mašmaššu șehru when the tablet was copied.

7 E.g., Robson 2014, 2011a; Maul 2010a; Gesche 2001: 213; Pearce 1993; Hunger 1968: 9-10. 
$L K A 89+$ is a two-columned tablet with incantations and ritual instructions against ghostly afflictions. ${ }^{8}$ These instructions aimed to free the patient of a ghost and to banish it to the netherworld, taking the generic "Any Evil" (mimma lemnu) with it. ${ }^{9}$ Ghosts were regularly treated in Kișir-Aššur's texts, and he had previously treated the effects of these to some degree in the šamallûu şehru manuscript $\mathrm{N}_{4}$ no. 237 and the presumed šamallû șehru tablet BAM 9 . Interestingly, $L K A 89+$ is described as an extract, although it is a library copy (multi-columned).$^{10}$ The reason for this discrepancy could stem from the text having been copied from a writing-board and originally having been part of an even bigger text. It is therefore possible that the nishu label could describe both multi-columned tablets as well as brief extracts in $\mathrm{N}_{4} \cdot{ }^{11}$ As a result, it can be difficult to establish what purpose a text served after its immediate use in the $\mathrm{N}_{4}$ collection. The multi-columned format could perhaps indicate a wish to keep the text for reference in the library afterwards, ${ }^{12}$ although in the case

For the most recent edition and copy, see $C M A w R 2: 189 \mathrm{ff}$. text $8.25 \mathrm{~ms}$ B; see also Scurlock 1988a no. 85, 87; Ebeling 1931a: 122ff.; cf. Abusch 2002: 76-78; Bottéro 1983. The join between $L K A 89+$ and $L K A$ 9o was previously noted by Pedersén 1986: 72 no. 523; see also Verderame 2008: 56 .

9 Abusch 2002: 76-77. The removal of mimma lemnu is also frequently stressed in the IštarDumuzi incantation rituals (Farber 1977: 9). Ghost rituals were also used in, e.g., bit rimki and the New Year festival, and were therefore not exclusively related to healing, but also stately or royal rituals (see Ambos 2013a: 52, 57ff., 201ff.; Scurlock 1988a: 127). Large parts of the row of entries and content are duplicated in the multi-columned KAR 227 (= $\mathrm{N}_{4}$ no. 88) written without a colophon. However, the end of $L K A 89+\mathrm{col}$. iv cannot be found on $K A R$ 227. Although large parts of $L K A 89+$ are broken and cannot be assessed, the differences observed are on the reverse in col. iii of both examples, where the incantation in $K A R 227$ col. iii 8'-24' is duplicated in $L K A 89+$ col. iii $2{ }^{\prime}-17^{\prime}$. The $L K A 89+$ entry opens with ÉN, which is not written in $K A R 227$. Furthermore, $L K A 89+$ col. iii 17 ' and the small instruction in 18' were divided onto two lines each in KAR $227 \mathrm{col}$. iii 13'-14' and 15'-16'.

$10 \quad$ LKA 89+ col. iv 9': [(x) x x x x x x $]^{\top} \mathrm{x}^{\top}$ na-as-ḩa. Presumably, the line read hanțiš or zamar before, but the line ends with nasha written very tightly, and likely more than three signs were originally on the line. It is therefore difficult to account for so many broken signs without considering that the line originally contained another statement, such as a purpose statement (ana șabāt epēši; see KAR 374 rev. 21; LKA 157 col. iv 12'). Such statements are argued in Section 7.4 to occur around the mašmaššu-phase. However, other texts only contain the hanțiš nasāhu statement on the last line, although the lines could easily hold more signs (BAM 81 rev. 18'; BAM 186 rev. 34; BAM 188 rev. 13; BAM 351 rev. 15; cf. $B A M 333$ rev. 4'). $L K A 89$ + is said to be "written and checked according to its original", $L K A$ 89+ col. iv 5': LIBIR.RA.BI.GIM AB.SAR.ÀM bà-rì.

11 It is unclear if nasăhu always designates extracts in $\mathrm{N}_{4}$, or if the verb could be used to designate a copy (cf. Black 1985).

12 This suggestion is built on the assumption that such formats normally served such purposes. However, this cannot be substantiated, although this was likely the case at Nineveh. Robson (2014: 146-47) has shown that this collection was in fact atypical in 
of $L K A 89^{+}$, the format may simply imply that Kișir-Aššur needed to copy out more text than what could be copied onto a single columned format tablet.

$L K A 141$ contains at least two prayers and accompanying ritual instructions (Pedersén 1986: 73 no. 543), which concern one(?) ritual for reconciling a man with the god (or goddess) of his house (Ebeling 1953a: XIII). ${ }^{13}$

$\mathrm{N}_{4}$ no. 24 was designated as a "recitation to calm a child" (KA.INIM.MA LÚ.TUR HUUN.GÁ.KE $\left.{ }_{4}\right){ }^{14}$ The term translated as "child" here, șehru or šerru, can also designate a baby or an infant (see Farber 1989:132-36). The incantation revolves around the demoness Lamaštu and therefore does not contain typical lullaby-like child calming motifs (e.g., Farber 199oa). Instead, it describes how Lamaštu stalks around a house and among the domesticated animals, luring the children to her venomous teats (Farber 2014: 301; Wiggermann 2000: 231 and note 93). The unsettling fear established by the crying of an infant heralded the presence of Lamaštu (ibid.: 237; Cadelli 1997: 26), and the family's ancestors and domestic cult could be severely disturbed by children crying (Stol 2000: 212-13; van der Toorn 1996: 18-19, 121, 125).

Lamaštu was the daughter of Anu, she killed babies by posing as a midwife and was formally installed by the gods to keep population growth in check (Wiggermann 2000: 224-25). She preferably attacked babies and pregnant women by causing a number of symptoms (e.g., fever, intestinal problems, red rash) related to other illnesses (e.g., jaundice, pašittu) potentially leading to death (Wiggermann 2000: 236-39; Stol 2000: 210). Problems during pregnancy and birth as well as protecting and curing ill babies were all part of ăšipūtu, and these areas are therefore expected to appear during the training of exorcists. ${ }^{15}$

The themes encountered during this particular level of education appear to revolve around the cult of the house, i.e., the family cult, the personal deities attached to a house as well as calming infants crying, and how to appease and

several ways. In general, good copies could have been kept as library copies to replace older tablets in worse condition, although this would not necessarily depend on format (Clancier 2014: 46).

13 LKA 141 rev. 2': KA.INI[M.M]A DINGIR LÚ KI LÚ ' $\mathrm{x}^{\top}[\mathrm{x} \mathrm{x} \mathrm{x}(\mathrm{x})]$. The first prayer mentions in obv. 1: ... lu-u DINGIR É lu-u ${ }^{\mathrm{d}} 15$ É $l u-u$ DING[IR LÚ? ...]. Furthermore, this colophon is the only instance where Kișir-Aššur writes the divine element of his father, Nabû-bēssunu's name phonetically: na-bi-um. However, the spelling is peculiar. The tablet remains unedited.

14 Farber 1989: 102-107 ms L, pl. 13; Farber specifies that such incantations could serve to calm a crying child, to heal an ill child or to protect a child from dangers prophylactically (ibid.: 3; George 1993b; cf. van der Toorn 1996: 120).

15 Jean 2006: 66; Geller 2000: 245, 256-58; Stol 2000: 59ff.; KAR 44 obv. 15: MUNUS NU 「el-lu] míPEŠ ${ }_{4}$.KÉŠ.DA míLA.RA.AH 'DIM ${ }_{8}$.ME.KÁM $u$ LÚ.TUR.HUN.GÁ, "(When) a woman is unclean Woman not able to give birth, travailing woman in difficulty because of Lamaštu, (incantations) to calm a child". 
remove the evils induced by the divinities' dissatisfaction with the inhabitants. Apart from the possible uses to treat the cause behind an illness, ${ }^{16}$ reconciling a man with his god and treating ghosts as causes of domestic troubles implies that something could upset a household's various deities. In the first half of the second millennium, crying children were notorious for disturbing the peace of the family, as well as the domestic cult (van der Toorn 1996: 120-21, 125-28; cf. Farber 1989: 1-4; Farber 1990a), and sleeping or resting gods evidently considered noise a disturbance. ${ }^{17}$ With $\mathrm{N}_{4}$ no. 24, Kișir-Aššur became able to calm a child and prophylactically keep Lamaštu at bay while ensuring that domestic cultic aggravation, which he also learned to handle as šamallû mašmaššu sehru, was less prone to happen.

Although one can only consider this evidence tentative, Kișir-Aššur appears to have learned these genres in order to remove domestic misfortune and possible sources of illness. Exorcistic healing of illness appears to have involved a dual approach by ritually soothing the anger of the divine cause and providing a physical treatment (Heeßel 200o: 94-96; cf. Stol 1991-92: 44ff.; van der Toorn 1985: 67ff.). Kișir-Aššur may therefore have focused his attention on the latter during his šamallû șehru-phase in particular, whereas especially the šamallûu mašmaššu șehru-phase could have focused on soothing (possible) causes of illness. As stated above, it is unknown if the rituals were learned in order to treat possible estranged divinities before illness, or as a dual approach while healing illness. Furthermore, as argued in the following sections, N4 no. 24 may inidicate that Kișir-Ǎšur also had pediatric duties during his šamallû mašmaššu șehru-phase.

\subsubsection{The Child Calming Incantation N4 no. 24 and Duplicates}

Kișir-Aššur's nephew, Kiṣir-Nabû, copied roughly the same Lamaštu incantation as Kiṣir-Ǎšsur's N4 no. 24, although Kișir-Nabû produced his copy as mašmašš and included a ritual. ${ }^{18} \mathrm{~N}_{4}$ no. 24 contains no ritual instruction and deals explicitly with Lamaštu and is intended to calm a child, whereas the

16 Koch unpublished: 11 and note 63; Heeßel 2007b: 127-28 and notes 28-29; Heeßel 200o: 81-86; cf. van der Toorn 1985: 123; Lambert 1974: 267-322.

17 Heffron 2014: 88-93; Stol 200o: 211-213; van der Toorn 1996: 18-19, 121, 125; Farber 199oa: 146-47. A frequently cited example is the motif of noise in Atra-hasīs causing Enlil to become so angry it results in the flood (Lambert and Millard 1969). Michalowski (1990: $385^{-89}$ ) argues that the metaphor of noise in mythological narratives "establishes a privileged position for the concept of creation, activity, independence", which in Atram-hasīs asserts humanity as "an independent, creative being" (ibid.: 389). Therefore, he does not regard noise as a literal mark of overpopulation. See also Machinist 1983 for noise as a motif in the Erra Epic.

18 N4 no. 247; see Farber 2014: 300-301; Farber 1989: 102-107 ms K, pl. 12; cf. Köcher 1949: $22-27$. 
ritual instruction in Kișir-Nabû's $\mathrm{N}_{4}$ no. 247 indicates that the purpose was to keep the child safe by applying ingredients to the child to keep Lamaštu, as well as "Any Evil" (mimma lemnu), at bay. ${ }^{19}$

The colophon of Kișir-Aššur's N4 no. 24 contains a tablet designation, his name, and a title. The tablet is labelled as an IM.GÍD.DA (lit.: "Long tablet"), a label interpreted in other studies as an exercise (see Ch. 6 notes $4^{-5}$ ). In comparison, Kișir-Nabû's N4 no. 247 was categorized as an u’iltu, perhaps indicating an obligation of some sort (see Section 5.3.2). N4 no. 247 was copied when Kișir-Nabû was mašmaššu, and it was copied according to a Nineveh(?) writing-board copied from Nippur. ${ }^{20}$ Kișir-Aššur provided no copying statement for his content in $\mathrm{N}_{4}$ no. 24. Kișir-Nabû's $\mathrm{N}_{4}$ no. 247 contains several Assyrianisms not present in Kișir-Aššur's duplicate, despite $\mathrm{N}_{4}$ no. 247 being copied from an alleged Babylonian original (Farber 1989: 103, 105; cf. Farber 2014: 210). Other minor differences in choice of spellings and line division are present in $\mathrm{N}_{4}$ no. 24 and $\mathrm{N}_{4}$ no. 247 , although it is currently unclear if the alterations stem from differing recensions (Farber 1989: 103-7). One example of such differences between the texts is:

$\begin{array}{lllll}\mathrm{N}_{4} \text { no. } 247 & \text { obv. 2 } & \text { ap-re-e-šá } & \text { up-pu-rat } & \text { AGA-š[á ...] } \\ \mathrm{N}_{4} \text { no. 24 } & \text { obv. 2-3 } & \text { up-ru-šá } & \text { up-pu-rat }{ }^{3} & \text { a-ga-šáap-rat } \\ L K U 3^{2} & \text { obv. } 12 & \text { up-ri-šá } & \text { up-pu-ra }[t \ldots & ]\end{array}$

The later Babylonian duplicate $L K U 3^{2}$ also shares features with both $\mathrm{N}_{4}$ no. $24,{ }^{21}$ as well as $\mathrm{N}_{4}$ no. $247{ }^{22}$ Thus, it is unclear how many recensions these three texts represent. Notably, the IM.GÍD.DA $B A M 102$ copied by Kiṣir-Aššur

19 Cf. Farber 2014: 35, 301; N4 no. 247 rev. 19, 22-23: [DÙ.D]Ù.[B]I(?) ... ${ }^{22}$ ÉN an-n[i]-t[ú] 3-[šú] ŠID-nu LÚ.TUR [ŠÉŠ] ${ }^{23}$ mim-ma HU [L $u$ ] dìM.ME [NU TE-šú] (Farber 1989: 104-105). Incantations against mimma lemnu also appear on Lamaštu amulets (Wiggermann 20oo: 220). The incantation is stated to be for "fumigation and stones" (rev. 18: $a[n]-n[a] m 3^{\text {?- }}$ [š] u ina $\mathrm{UG}\left[\mathrm{U} x^{?} q\right]$ u-ta-ri u? $\mathrm{NA}_{4} \cdot \mathrm{ME}[\check{S}$ ŠID-nu(?)], Farber 1989: 104-5).

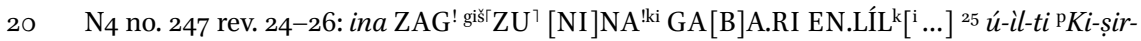
dPA MAŠ.MAŠ ša [... ${ }^{26}$ DUMU p.dUTU-Ù.TU MAŠ.MAŠ DUMU p.dPA- $b[e-\ldots]$.

21 Mainly choice of words and writings, for example:

N4 no. 24 obv. 5 du-ra-niš ${ }^{\ulcorner} u s^{\swarrow}-t a-n a-a ́ r$

N4 no. 247 obv. 4 șe-ra-niš ut-ta-[na-šak(?)]

LKU 32 obv. 13 du-ra-niš uš-ta-na-ár ...

Farber (2014: 35) noted that $L K U 32$ contains "several Assyrianisms not present in the Assur 'version", which is presumably represented by Kișir-Aššur's N4 no. 24. However, Kișir-Nabû's N4 no. 247 also contains Assyrianisms (Farber 1989: 103).

22 Especially the ritual instruction. $L K U 3^{2}$ also contains at least three other associated incantations and ritual instructions. 
as mašmaššu is largely similar in structure to $\mathrm{N}_{4}$ no. 24, i.e., only an incantation and an explicit statement about not having written a ritual, which could indicate that Kișir-Aššur was practicing certain shorter incantations for a specific purpose during these phases (see also the šamallû șehru manuscript $\mathrm{N}_{4} \mathrm{~A} 400$ ). Comparably, his father Nabû-bēssunu copied $K A L 4$ no. 6 as mašmaššu șehru, and this tablet likely only contained a single prayer related to a namburbi-ritual.

\subsubsection{Excursus: Paediatricians and Treatments}

Unlike veterinarians, no titles are known for ancient paediatricians, but only for midwives. ${ }^{23}$ Nevertheless, the exorcist was involved in assessing the physiognomy of humans in general, as well as providing prophylactic or therapeutic treatment of children. ${ }^{24}$ The 4 oth tablet of Sa-gig attests to 112 diagnoses of child symptoms (Volk 1999: 13; Cadelli 1997: 12-13). ${ }^{25}$ The most dominant among the problems diagnosed are behavioural problems, such as the ones presumably treated by $\mathrm{N}_{4}$ no. 24, and digestive disorders such as colic (Cadelli 1997: 26, 29). ${ }^{26}$ Although age is rarely specified, the entries may often concern newborns as well as babies (Cadelli 1997: 13).

Already during pregnancy, Lamaštu and witchcraft could pose a threat to the unborn child (Cadelli 1997: 15). Some demonic beings could even be born with the child, such as Lugal-urra or Šulpaea (Cadelli 1997: 15; Stol 1993: 89). This portended a scattered house (Volk 1999: 18 note 108). Cramps associated with epilepsy were particularly ominous (ibid.: 16-17; Cadelli 1997: 23-24). These symptoms could foreshadow a fatal end for mother, father or the entire household (Volk 1999: 17 and note 102; Stol 1993: 89). ${ }^{27}$ Jaundice (ahhāazu in

23 ов Mari was probably famous as a centre for healing child illnesses (Volk 1999: 29-30 and notes 179-80 with references). For midwives, see Stol 2000: 171-76.

24 Steinert 2018c: 181; Böck 200o: 32, 313, 315; Stol 200o: 59-72. However, the exorcist is advised not to see the mother for a duration of one month after birth (Stol 2000: 206). Note that at least one incipit related to birth is only attested in the $\mathrm{N}_{4}$ text collection (Steinert 2018d: 272; N4 no. 167).

25 The general writing is LÚ.TUR for "baby, newborn, infant, child", which can be read šerru, the more literary la' $\hat{u} / l a k \hat{u}$, or the common designation for a child șehru (Stol 20oo: 176; cf. Volk 1999: 12 note 73 with references to discussion).

26 Infant colic can present itself as a regular occurring emotional response involving crying, screaming and occasional difficulty in breathing because of the "fussing", combined with physical manifestations such as stomach pains, regurgitation and diarrhoea (Hyman et al. 2006: 1522-1523; Wessel et al. 1954).

27 See also Sa-gig tablet 29, in which various ominous portents are specified if a child is born with Antašubba or Šulpaea or if these demons fall on a child during various periods of the child's life (Scurlock 2014: 219-220; Heeßel 200o: 318-338). 
tablet 40), which could signal the presence of Lamaštu in children, ${ }^{28}$ was also considered ominous, and the birth of a yellow child heralded the death of the owner of the house. ${ }^{29}$

Some physical symptoms could therefore herald the destruction of a household. Treatments safeguarding the household and keeping it in balance were essential, and such purposes seem to correspond to Kișir-Aššur's šamallûu mašmaššu șehru texts and large parts of his mašmaššu texts concerning, e.g., namburbi-rituals (see Sections 5.2 and 6.4).

Little is known about what therapeutic treatments for diseases were applied to babies. ${ }^{30}$ The best information stems from the NA royal correspondence, ${ }^{31}$ although we often find only brief remarks that a child is doing well. ${ }^{32}$ Nontheless, some exorcists practicing at the contemporary NA royal court at Nineveh, may been involved in observing and healing infants or children in addition to adults (e.g., Parpola 1993 nos. 213-215, 218, 302, 305). Volk (1999: 11) regarded it as a chance of discovery that child treatments are so poorly documented in medical literature. However, child healing is not listed as an identifiable category in the AMC. ${ }^{33}$

Nonetheless, many illness diagnoses for children are attested in "adult" versions (Cadelli 1997: 32). It is therefore plausible, although impossible to prove, that at least older children received the same (modified) treatments as adults

28 Lamaštu was known as "the goddess who (makes) his face yellow" ul-tú `ša IGI-šú SIG (Volk 1999: 24 note 137 with reference).

29 De Zorzi 2014: 441; Cadelli 1997: 31; Leichty 1970: 66; tablet 4 line 5: [BE SAL Ù.TU]-ma MIN-ma (= ul-la-nu-um-ma) SIG 7 ma-[li] EN É ÚŠ, "If a woman gives birth, and at the birth (the child) is already fully yellow (Leichty: flecked with green (spots)) - the owner of the house will die."

30 For boy's problems, see George 2016: 167-68. Note $B A M 248$ col. iv 39-43 with prophylactic treatments for keeping "hands" of various deities from approaching infants (Scurlock 2014: 626ff.). Scurlock (ibid.: 621) furthermore states: "Treatments specifically and exclusively designed for infants or toddlers are relatively rare and usually scattered among prescriptions for adults with similar problems." For additional examples of treatments for adults or children, as well as cures exclusively for children, see Steinert 2018d: 228 .

31 Volk 1999: 8. Letters mentioning children's health, regardless of age and description: SAA 10 no. 187, 193, 194, 196, 197, 202, 213, 214, 215(?), 217, 218, 219, 222, 223, 231, 238, 239, 244, 245, 247, 293, 296, 298, 299, 300(?), 301, 302, 304(?), 305, 306(?), 309, 319, 320, 321, 322, 323.

32 The evidence from the antechamber to the third NA tomb at Nimrud showed several individuals ranging 6-12 years of age, a fully grown foetus (8th-9th lunar month), and a baby (3-9 months) (Macgregor 2012: 81; Müller-Karpe et al. 2008: 144). Although these individuals must date to the 8 th century, it is uncertain whether or not these were royal children.

33 Apart from pregnancy and birth which occur near the end of the AMC, the best candidate is an earlier entry in line $98:[\ldots]]^{\ulcorner}$ana ${ }^{\mathrm{d}} \mathrm{DIM}_{9}{ }^{7} \cdot \mathrm{M}[\mathrm{E}] \mathrm{Z}\left[\mathrm{I}-h i^{?} \times \mathrm{x} \times \mathrm{x}\right]$, "for era[dicating(?)] Lamaštu $[\ldots] "$. 
(ibid.: 33 note 159) $\cdot{ }^{34} \mathrm{~A}$ human adult treatment was perhaps also modified into at least one horse prescription in BAM 159 (Stol 2011: 395 and note 223; cf. Böck 2009a: 117-18). I would also like to emphasize the recent findings by Heeßel (2006: 19-20) concerning the possible lack of differences between the treatment of men and women in major parts of the first 35 tablets of Sa-gig. This could indicate that the diagnostic and therapeutic corpora may not always have been applied exclusively to the identified gender, even species, and perhaps also age group.

In relation to horses in particular, it is noteworthy that they and children are prone to nasal breathing and regurgitation (Section 4.4.2). ${ }^{35}$ Furthermore, gastro-intestinal disorders are regularly observed in both horses and infants (Hyman et al. 2006:1519; Gonçalves et al. 2002: 643). This may indicate an overlap in physiological conception, and due to the possible physiological knowledge taught to Kișir-A ššur as šamallû șehru concerning horses, we can perhaps hypothesize an overlap between some child and horse illnesses, and maybe adult treatments for similar problems. ${ }^{36}$

34 The AMC may indicate that conditions occurring in both children and adults were integrated into the adult sections of such medical texts, e.g., AMC line 23 adds šá LÚ.TUR and AMC line 28 adds $\grave{u}$ LÚ.TUR su-alu GIG (Steinert 2018d: 227-228, 230). However, such cures are not found in the majority of therapeutic manuscripts, and the phrases above could therefore indicate that the prescriptions for adults referenced in AMC line 23 and 28 could be modified and applied to children.

35 It is unclear if Sa-gig tablet 40 lists any cases of "regurgitation", although it may be described by the verb šurruhu (Cadelli 1997: 17, 20, 30; cf. Scurlock and Andersen 2005: 749 note 120). It therefore remains uncertain if "regurgitation" was differentiated from "vomiting" in terminology (cf. Volk 1999: 20-21; see translation by Scurlock 2014: 263-269).

36 This would require an understanding of how little medication a baby or an infant would need. Today, presumably as in ancient times, children are usually treated for issues connected to nutrition, common and infectious diseases, as well as injuries or trauma (see, e.g., Scurlock and Andersen 2005: 410ff.; Cadelli 1997: 20-21, 27-29). It is noteworthy that such issues are often treated similarly regardless of age. However, symptoms of diseases can be subtler in babies, and the physician must diagnose beyond specialization. Yet, there is generally little doubt when a child is in pain. Paediatricians today assess pain in infants and young children via a variety of pain scales in order to determine their levels of discomfort (e.g., Beltramini et al. 2017). Infants are prone to non-epileptic motor phenomena, such as tremors, jitters, forms of myoclonus, and brainstem release phenomena (Huntsman et al. 2008). The ancient medical texts seem to focus on such experiences in relation to the infant's motor system because they could foreshadow severe afflictions, which in turn could affect the entire household (Volk 1999: 16-17; Cadelli 1997: 23-24). These problems would therefore have been a matter of concern for a healer regardless of the medical knowledge gained from treating children. Practicing on infants and children would have allowed a healer to study failures to thrive in a non-verbal environment, how the body communicates problems and levels of pain under such conditions, as well as sharpening their diagnostic abilities, regardless whether or not this could be transferred 


\subsubsection{An Interpretation: Kișir-Aššur as Paediatrician?}

In Section 4.2.2, I suggested that Kișir-Aššur might have worked (alongside his father) with animals, perhaps only horses, in addition to humans after having acquired veterinarian knowledge as šamallû șehru. Following this line of reasoning, the evidence presented here tentatively suggests that he may have moved on to (aid his father when) treating infants, babies or children at least as šamallû mašmaššu șehru. In addition to the obvious dangers of doing more harm than good when practicing medicine, there may have been an economic and ethical value system explaining why practicing on ill animals and babies provided more professional security than on human adults. ${ }^{37}$

In comparison, the ов laws of Hammurabi contain several clauses for both physician (asû) and veterinarian (asî alpim ulu imērim) accidents or malpractice, which are instructive for understanding what was at risk. Although law collections such as the laws of Hammurabi may not reflect actual practice, and instead relate to "cultural assumptions and values of their drafters and copyists" (Roth 1995: 4-7 with references), ${ }^{38}$ they certainly reflect a concern for justice when wronged, which can be used to emphasize tendencies towards punishment:

LH paragraph 218: "If a physician (asûm) performs major surgery with a bronze lancet upon an awilum-man and thus causes the awilum's death, or opens an awilum's temple with a bronze lancet and thus blinds the awilum's eye, they shall cut off his hand" (Roth 1995: 123). ${ }^{39}$

directly to adults. These observations were formulated following a personal communication with Elisabeth Lund, chief paediatrician at Kolding Hospital, Denmark. However, it is also possible that Kișir-Aššur copied the incantation $\mathrm{N}_{4}$ no. 24 because he himself became a father around this time (JoAnn Scurlock, personal communication). It cannot be excluded that some texts were copied by Kișir-Aššur for reasons unrelated to his profession, similar to one of Nabû-zuqup-kēnu's manuscripts containing the 12th tablet of the Gilgameš Epic (Frahm 1999).

37 One example is the area of surgery, although it is unclear who practiced this in most periods outside of the ов period where the as $\hat{u}$ is mentioned in this role in the laws of Hammurabi (Böck 2014a: 19-20; Geller 2010: 53, 56, 58, 6o-61). Even today, there are potential problems related to infections during surgery, and the occasional threat in incantations concerned with "the obsidian blades of Gula" (șurrū naglabū Gula) emphasizes that this was likely considered an equal threat to illness and patient alike as a last resort (Böck 2014a: 19; Geller 2010: 3, 54; Collins 1999: 94, 217-18, 233).

38 Johnson 2015: 295-300 and Charpin 2010b: 77-82 and note 43 with further references; see also Westbrook 2003: 17-21. See Guinan 2014: 117 on laws in relation to omens.

39 However, other rules applied if the man was a slave of a commoner (muškēnum), see paragraph 219-20. 
LH paragraph 225: "If he (i.e., a veterinarian, asî alpim ulu imērim) performs major surgery upon an ox or a donkey and thus causes its death, he shall give one quarter(?) of its value to the owner of the ox or donkey" (ibid.: 124).$^{40}$

Causing the death of an ox or donkey while performing surgery on it resulted in a fine of one-fourth(?) of the animal's value. However, if a physician caused a man's (awìlum) death or blinded his eye during surgery, he would have his hand cut off, effectively ending his practice. Therefore, less may have been at stake when treating an animal compared to an adult. Although the laws of Hammurabi stem from the ов period, they were actually copied, probably for their historic value, in the $\mathrm{N}_{4}$ collection. ${ }^{41}$ Still, we do not know if regulations for malpractice stipulated in the laws of Hammurabi are applicable to the āšipu's trade.

Children are not mentioned in the extant law collections in relation to healing, but it must be considered certain that infants were vulnerable during pregnancy and in the time following birth, and that they were occasionally in need of medical assistance (Stol 2000: 27-48, 129-34, 209-14). ${ }^{42}$ It is therefore plausible that the failed healing (or assisted delivery?) of a prominent family member's baby could damage your reputation, although you may have been allowed to continue your practice elsewhere. ${ }^{43}$ If this analysis is correct, it is possible to identify three hypothetical and generalized steps with increased professional consequences as a result of a failed healing:
1) Animals
$\rightarrow$ Economic penalty
2) Infants, babies $\rightarrow$ Damaged social reputation/social exclusion
3) Adults
$\rightarrow$ Physical penalty/termination of practice

This could imply that some apprentice healers, if trained in all such treatments, may have had greater autonomy when healing animals and babies, as the cost of failure would have been more manageable in terms of continuing

40 One fourth or one fifth of the price is unclear (Roth 1995: 142 note 41).

41 Ismail 1982: 199. It is currently unknown if the content related to the laws or the prologue.

42 For birth at the NA court, see Melville 2004: 37 note 1, 42-43, 47. For birth incantations, see Couto-Ferreira 2017: 58, 6o, 64; Böck 2009c: 272-74; Stol 200o: 59-71. Concerning birth, see Steinert 2018d: $272-76$ with further references. It seems the death of a child could be associated with misfortune (ibid.: 269-270 with further references). 
his career. ${ }^{44}$ In these cases, it is likely that the apprentice gained autonomy in treating animals such as horses before babies, which in turn were treated with greater autonomy by the apprentice before adults. However, this remains hypothetical. It should be kept in mind that medical healing often had a religious aspect. In relation to rituals, the success of such performances may have depended on the gods (see Ambos 2010: 17-18). Although healers were likely to be held responsible to some extent for failed healings, it is possible that failure could be interpreted as the will of the gods. ${ }^{45}$ Yet, no available sources describe the consequences of an unsuccesful treatment by an āšipu.

The hypothesis above may, however, be tentatively substantiated in relation to Kișir-Aššur's career. As shown in Section 3.5, Kișir-Aššur's šamallûu ssehru tablet $R A{ }_{15} \mathrm{pl} .76$ relates to venomous stings and bites as well as horse treatments (colic?). This tablet may therefore relate to knowledge acquisition or perhaps even practice in these areas of treatment. Kișir-Aššur's šamallû mašmaššu șehru tablet $\mathrm{N}_{4}$ no. 24, discussed above, relates to prophylactically treating a child. The evidence is therefore vague and limited. A number of texts copied by Kișir-Nabû and related to children and pregnancy are copied during his mašmaššu șehru- and mašmǎ̌šu-phases, thus indicating such material belonged to later phases.

The surviving evidence indicates that Kișir-Aššur may have worked with treatments related to horses before children, although he also copied adult treatments as šamallû șehru. Though it is possible that Kișir-Aššur aided in practicing on adults alongside animals and children throughout his apprenticeship, I draw on the value system outlined above to suggest that he may have experienced greater autonomy when treating on animals and children before becoming an autonomous healer of adults as well. I therefore hypothesize that Kiṣir-Aššur, in addition to periodically aiding his father with a range of healing activities, may have had greater autonomy when treating horses (and other animals?) and babies before moving on to practice healing on human adults without supervision as mašmaššu.

44 Adults were probably also the most valuable members of a household to keep healthy. Furthermore, adults would also have been able to complain verbally, whereas animals and babies can mainly communicate their distress non-verbally if crying and screams are disregarded.

45 For a survey of ritual failures and mistakes, see Ambos 2007. Some texts stress illnesses that the healer should not attempt to heal (Schwemer 2011: 434). 


\subsection{The mašmaššu șehru-phase}

Kișir-Aššur's "junior exorcist" mašmašsu șehru-phase is poorly attested, with only one text preserved. Sadly, the manuscript is unpublished and little is known about the content. Nonetheless, a few observations can still be made.

Although the exact content of $\mathrm{N}_{4} \mathrm{~A}_{2727}$ is currently unknown, the text contains two incantations with instructions for application, of which the first incantation duplicates BAM 105 obv. 1-6 and presumably also STT 97 col. iv 25-29 (Daniel Schwemer, personal communication). This brief incantation mentions various (gynaecological?) problems concerning a young woman, ${ }^{46}$ although the brief ritual instruction in $B A M 105$ obv. 7 explains that the incantation was widely used, as it could be recited over any suppository, ointment and enema against "Anus illness" (DÚR.GIG) (Section 8.4.1; see also Kị̣irAššur's BAM 102 in Section 6.1). Therefore, it is unclear against what problem $\mathrm{N}_{4} \mathrm{~A} 2727$ was directed. However, considering the widely applicable use of the incantation and instruction in $B A M$ 105, it does not seem accidental that $\mathrm{N}_{4}$ A 2727 contains the label "tested prescriptions, which are suitable for use(?)" (bulți latkūti ša ina qāti šusșû). These are presumably the earliest prescriptions labelled as "tested" (latku) copied by Kiṣir-Aššur (see Section 8.3). The phrase ša ina qăti šusşû seems to indicate the treatment in question was considered especially useful, although the exact nuances are uncertain (see Ch. 6 note 25).

TABLE 8 Texts assigned to Kișir-Aššur's mašmaššu șehru-phase

\begin{tabular}{ll} 
Text Content & $\begin{array}{l}\text { Format and } \\
\text { designation }\end{array}$ \\
\hline
\end{tabular}

N4 A $2727 \quad$ Obverse and reverse: two incantations Landscape; $u^{\prime} i l t u$

with instructions, of which one may have

been against "Anus illness"

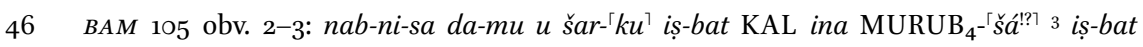
KI.SIKIL ina pag-ri-šá. Perhaps the incantation concerned menstruation or a severe gynaecological problem. It was certainly employed for "Anus illness" on account of the associated bleeding. The association between menstruation and bleeding from male pelvic orifices were also used in diagnoses concerning "if a man passes blood from his anus" or "if a man's penis drips blood", see Stol 2016: 438; Geller 2005: 40-41, 68-69, 94-95, 104-105, 140-141, 188-189, 212-215, 218-219. 
Noticeably, only around five tablets represent the various Bāba-šuma-ibni family members' mašmaššu șehru-phases. ${ }^{47}$ This observation could tentatively indicate that this family did not keep tablets, did not inscribe their names or titles, or kept their tablets elsewhere during the mašmaššu șehru-phase. KiṣirNabû probably copied three tablets related to pregnancy and babies during his mašmaššu șehru- and mašmaššu-phases. In combination with Kișir-Aššur's child-calming incantation $\mathrm{N}_{4}$ no. 24 , the evidence indicates that such material belonged to the šamallû mašmaššu șehru, mašmaššu șehru and mašmaššu phases. ${ }^{48}$ However, he also copied a tablet with prescriptions for skin illnesses of the head (BAM 33) and a commentary to the incantation tummu bitu and Šurpu tablet 2 ( $A f O 12 \mathrm{pl}$. 13-14) as mašmaššu șehru. At least the first incantation in Kișir-Aššur's N4 A 2727 was a tested remedy used elsewhere against "Anus illness".

\subsubsection{Discussion of the mašmašsu șeḩru-phase}

Little is known about the concrete competences demanded during the "junior" (șehru) phases of various professions. For the MA period, Wagensonner has elucidated various aspects concerning the training of three țušarru șehrus who were sons of the MA royal scribe Ninurta-uballissu (Wagensonner 2014a; Wagensonner 2014b; Wagensonner 2011: 647-49). At least two of the brothers wrote tablets or controlled each other's work. ${ }^{49}$ Although we cannot determine if they were still engaged in a learning process at this stage, Wagensonner (2011: 649) considered it likely they were already at the peak of their education (cf. ibid. 2014b: 459).

47 See Kișir-Nabû's mašmaššu șehru tablets $A f O 12$ pl. 13-14, BAM 33 and perhaps KAR 114(?), as well as Nabû-bēssunu's KAL 4 no. 6; cf. Maul 2010a: 208-10. KAR 114 contains another child calming incantation and ritual (Farber 1989: 98-101 no. $32 \mathrm{~ms} \mathrm{~h}$ ).

Kișir-Nabû copied KAR 114 as mašmaššu (șehru?), rev. 11: ... MAŠ.[MAŠ (TUR?)], (almost no space), and LKA 143 and N4 no. 247 as mašmaššu (cf. Fadhil 2012: 37 note 2). See also KAR 223 for postponing a birth from happening in the first month of the year, which was copied by Kișir-Nabû without a title, but including the ša Nabû tuklassu-phrase (Stol 20oo: 93 and note 19 with references). Furthermore, knowledge related to children is also found in Late Babylonian scholarly texts from Uruk. Stevens suggested a correlation existed within this material between knowledge related to the professional specialism of a tablet owner and the occurrence of so-called protective formulae in the colophons (Stevens 2013: 211-12; see the discussion of such phrases in Section 6.2.3). If we accept this division, it would seem that diagnoses, treatments, and omens for women, birth, and babies were part of their specialization and this knowledge likely belonged to the mašmašš șehruand mašmaššu-phases of the Urukean scholars examined by Stevens (e.g., SpTU I no. 38, no. 48, no. 59, $S p T U$ III no. 9o, SpTU V no. 248; Stevens 2013: 234-36).

Wagensonner 2014b: 462; Wagensonner 2011: 649. 
In the LB scribal education, incantations against Lamaštu, as well as incantations from, e.g., Maqlû and $\breve{S} u r p u$, were copied in the second phase (Gesche 2001: 176). A brief catalogue of five related incantation incipits from the Lamaštu series, as well as a number of prescriptions for treating "Anus illness", are also among the medical school tablets published by Finkel (2000: 144, 195-96). Stevens (2013) also found some shared features in the LB Uruk ŠangûNinurta family's tablet collection, which might mark certain tablets as part of specialist training or as advanced pedagogical texts. These features included the tablets written by șehrus, designated as commentaries, being malsûtus or IM.GÍD.DAs (i.e., exercises; cf. Gesche 2001: 50), and containing errors, notes, or brief colophons without ownership or copying statements. ${ }^{50}$ Stevens suggests the "junior" status may have lasted "many months or even years" (Stevens 2013: 220-21).

Interestingly, in $S A A$ 10 no. 290 Urad-Gula writes to the king concerning the exorcist Nabû-le'utu and his son who was performing rituals with him: "Even I have noticed that this son of his is (still) in the unsteadiness of youth (șahhurānūtu)" (Parpola 1993: 277). ${ }^{51}$ Therefore, the participating son in this case was clearly considered immature. The question is if he was a (mašmaššu) șehru at this time. ${ }^{52}$

Considering that Kiṣir-Aššur also wrote at least two IM.GÍD.DAs as šamallû mašmaššu șehru and mašmaššu, we might consider it likely he was still in training as a mašmaššu șehru. In terms of content, Kișir-Aššur and his nephew tentatively appears to have been closer to the educational principles of the $\mathrm{LB}$ healers than the MA țupšarrus during his mašmaššu șehru-phase.

\subsubsection{Excursus: Kișir-Aššur's u'iltu-tablets}

Kiṣir-Aššur copied numerous tablets labelled as u'iltus throughout his career. Seeing as the label may in some contexts have had a pedagogical nuance (see below), I have included an excursus on the term in this chapter before examining Kiṣir-Aššur's mašmǎ̌šu- and mašmaš bit Aššur-phase in the following chapters. However, the exact nuances of the term u'iltu in the $\mathrm{N}_{4}$ text collection are poorly understood. Kișir-Aššur likely copied four such texts as šamallûu șehru, one as šamallû, one as mašmaššu șehru, possibly four as mašmaššu,

50 Stevens 2013: 219-20 and notes 49-54 and 56; Frahm 2011a: 313 note 1492, 314 note 1495. Kiṣir-Nabû's commentary $A f O 12$ pl. 13-14 was written as mašmǎ̌šu șehru. See also Pearce and Doty 2000: 337-41.

$5^{1}$ SAA 10 no. 290 rev. 15-s. 1: ... u a-na-ku ${ }^{16}$ a-ta-mar DUMU-šú an-ni-i ${ }^{\text {s.1 }}$ [ina] ŠÀ ba-ra-ar șa-huu-ra-nu-tú šú-u.

$5^{2}$ For NA apprentices, see Robson 2014: 152-53; Robson 2013: 50; Robson 2011a: 564-65. 
five as mašmaš büt Ǎ̌šur, and at least three during an uncertain phase. ${ }^{53}$ The u'iltu label was written systematically with the signs ú-il-tì/ti by Kișir-Aššur and Kișir-Nabû.

In the $C A D(\mathrm{U}-\mathrm{W}: 51)$, the word is translated as "a type of tablet about twice as wide as long, inscribed parallel to the longer axis containing a scholar's report, obligation, debt, promissory note, debt note" (see also AHw: 1405; Gesche 2001: 147), and it is further specified at Nineveh as containing astrological reports and generally having a ratio between its sides of $1: 2$ with a landscape format (Radner 1995: 72; Radner 1997: 6o-61; Parpola 1983a: 65; Parpola 1983b: 2 note 5; Hunger 1992: XV). The word originates etymologically from "to bind (by an agreement)" e'elu (CAD E:40;AHw: 189), and it is therefore related to something owed to someone. ${ }^{54}$ As mentioned in the $C A D$, u'iltu-reports were often written to the NA kings concerning celestial omens (Hunger 1992: XV). Scholars "kept the king's watch" (mașșartu ša šarri nașāru), which involved watching, guarding and protecting the king by ensuring he knew what course the gods had decreed for him (Parpola 1993: XXI-XXII). The inherent responsibility between observation and report may have been reflected in the label uiltu. As discussed in Section 5.3.2, the u'iltu label in $\mathrm{N}_{4}$ may tentatively designate the content as an exercise, obligation or commitment on behalf of the copyist. The word u'iltu can therefore cautiously be proposed in some instances to indicate a duty or exercise administered by, or made in relation to, a senior teacher, practitioner or colleague. There is currently no evidence to suggest that the label could also designate a healer's obligation in relation to a patient. None of KișirAššur's mašmaš bit Aššur-phase u'iltus are copied on his behalf, which suggests that Kișir-Aššur copied them himself. However, it cannot be excluded that the anonymous "written and checked" statement, spelled SAR-ma È, could hide a Š-stem of šațāru in some cases (see Section 7.4.2 as well as Ch. 3 note 134). This remains uncertain.

Noticeably, Kișir-Aššur's u'iltus all seem to be one-columned tablets in portrait format, which is unexpected (see also Maul 2019: 312). The only

53 Šamallû șehru: BAM 201; N4 A 400; N4 no. 237; N4 no 241(?); šamallû: N4 no. 175; mašmaššu șehru: N4 A 2727; mašmaššu: BAM 81; BAM 122; KAL 4 no. 7(?); KAR 230; mašmaš bït Aššur: BAM 300; KAR 62; KAR 63; LKA 83; N4 no. 110; broken title: KAL 7 no. 24(?); KAL 10 no. 13; LKA 137. Kișir-Aššur or Kișir-Nabû: BAM 26o; LKA 146.

54 By comparison, the ов galamāhu Ur-Utu from Sippar owned 46 letters referring to an etymologically similar "binding" (e'iltu) that was to be released (pațāru) by the gods, probably through a ritual (Tanret 2011: $283-284$ ). The word is translated "obligation, liability, sin" in $C A D$ (E: $\left.51^{-} 5^{2}\right)$, and in the case of Ur-Utu, it could lead to illness and the eventual loss of life (Tanret 2011: 283-284). 
exceptions appear to be Kișir-Aššur's three u'iltus $L K A \quad 83, \mathrm{~N}_{4}$ A 400 and $\mathrm{N}_{4}$ A 2727 in single-column, landscape format. Peculiarly, the majority of KisirNabû's u'iltus seem to be in the landscape format. Why Kișir-Aššur's u'iltus largely differ from the expected landscape format is unclear. Perhaps it was no different from choosing paper with lines over paper with squares (Ulla Koch, personal communication). There does not seem to be any distribution of such texts according to specific career phases or content (cf. Finkel 200o: 146). The meaning of the term and the shape of uiltus in general require further investigation.

\subsection{Excursus: The ša Nabû tuklassu-phrase}

At least five of Kiṣir-Aššur's texts contain the phrase "whose trust is Nabû" (̌̌a

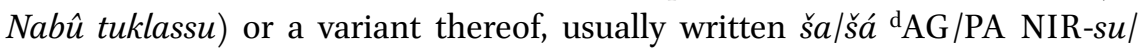
GISKIM-su/tuk-lat-su..$^{55}$ Of these texts, three can be attributed to the šamallû șehru-phase (RA $15 \mathrm{pl} .76)$ and šamallû mašmaššu șehru-phase (LKA 89+, LKA 141). This leaves two texts, $B A M 9$ and $B A M$ 121, which do not contain a title related to a career phase. Although Section 7.1 argues that Kișir-Aššur's tablets without titles belong to later career phases, the presence of this phrase in earlier phases could indicate that $B A M 9$ and $B A M 121$ belong somewhere before the mašmaššu-phase (see below). ${ }^{56}$ These two colophons read:

$55 \quad B A M 9$ rev. $72:\left[\ldots{ }^{\mathrm{d}} \mathrm{A}\right] \mathrm{G}$ tuk-lat-su ${ }^{\lceil\mathrm{d}\rceil}[T] a s ̌-m e-t u_{4}{ }^{\lceil} \mathrm{x}^{\top}[\ldots] ; B A M 121$ rev. 25: ... ša ${ }^{\mathrm{d} P A}$ NIR-su; LKA 89+ col. iv 6': ... šá dAG GISKIM-su; LKA 141 rev. 10': ... '̌śa ${ }^{1}$ [...]; RA 15 pl. 76 rev. 11': ... ša ${ }^{\mathrm{d}} \mathrm{PA}$ tuk-lat-su; cf. $K A L 4$ no. 37 rev. 8': [... NI]R-su. The last text was likely copied by Kișir-Aššur or Kișir-Nabû (see Section 7·3). Kișir-Nabû has at least nine tablets with this or similar phrases: CMAwR 1 pl. 25-26 rev. 27: šá a-na d [A]G $u{ }^{\mathrm{d} K U R N U N}[t] a$-ak-lum; BAM 52 rev. 103: ... šá dPA NIR?'-su; BAM 106 rev. 9': ... ša dAG tuk-[lat-su]; BAM 147 rev. 28': ... šá PA NIR-su; KAR 223 rev. 14: ... šá DAG NIR-su; LKA 100 rev. 8: ... šá dPA tuk-l[at]-s[u]; LKA

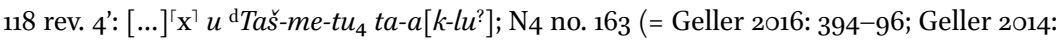
64ff.) rev. 26: ... šá d「NÀ NIR-su; N4 no. 247 rev. 25: ... ša [...]; cf. ct 15 pl. 43f. rev. 11 ': ... 'ša ${ }^{\mathrm{d}} \mathrm{AG}^{\urcorner}$tuk-lat-s[u]; KAL 4 no. 37 (see above); KAV 182 col. iv 9': [...] dAG tuk-lat-su. Notably, Kișir-Nabû regularly seems to choose the same Sumerogram for Nabû (PA/AG) as the theophoric element of his name.

$5^{6}$ Generally, the phrase ša Nabû tuklassu is included directly after the personal name of the copyist or owner of the tablet. However, Kișir-Aššur's BAM 9 and Kișir-Nabû's $L K A 118$ differ, and in $B A M 9$, Kișir-Ǎšsur writes an altered version of the phrase after his father Nabû-bēssunu's name (see below). Kișir-Nabû's texts published in CMAwR 1 pl. 25-26 and $L K A 118$ also show alternative formulations over this thematic sentence. 
BAM 9 rev. 69: [DIŠ NA] [UD.DA TAB 'BA!-ma SÍG SA[G.DU]-「šú? GUB.MEŠ EG[IR?-šú iš-šaț-țar]

BAM 9 rev. 70: [(nis-hu $)$ ] IGI-ú GABA.RI gišZU [x x x x x x x x x(?)]

BAM 9 rev. 71: [D]U[B (blank)] P Ki-șir-AN.ŠÁR DUMU p. ${ }^{[\mathrm{d} 7 \mathrm{AG}-b e ́-[s u n}$ lúMAŠ.MAŠ BAL.TIL ki/É AN.ŠÁR(?)]

BAM 9 rev. 72: $\quad\left[(\mathrm{x} \mathrm{x}\right.$ ? $)$ šá $\left.^{\mathrm{d}} \mathrm{A}\right] \mathrm{G}$ tuk-lat-su ${ }^{\lceil\mathrm{d}]}[T] a s ̌-m e-t u_{4}{ }^{\lceil} \mathrm{x}^{\top}[(\mathrm{x} \times \mathrm{x} \times \mathrm{x} ?)]$ BAM 9 rev. 73: [DUMU p.d $B] a-b a_{6}$-MU-DÙ lúZABAR.DAB.BA É-[šár-ra] BAM 9 rev. 74: [(nı̌š $\left.\left.{ }^{\mathrm{d}} \mathrm{PA} ? u^{?}\right)^{\mathrm{d}} \mathrm{AM}\right] \mathrm{AR} . \mathrm{UTU}$ šu-mi šaț-rù la $t[a-p a$-šit $]$ BAM 9 rev. 75: $\quad\left[(\mathrm{x} \times \mathrm{x} \text { ? })^{\mathrm{d}}\right] \mathrm{AG}\left\lceil\grave{u}^{\top} \mathrm{d} \mathrm{A}[\mathrm{MAR} . U T U]\right.$ BAM 9 rev. $76: \quad[(\mathrm{x} \times \mathrm{x} \mathrm{x} ?)]^{\top} \mathrm{x} \times \mathrm{x} \times \mathrm{x}-\mathrm{s}^{1}{ }^{1}-m[a(\mathrm{x} \times \mathrm{x} ?)]$

(Catch-line); 70 First [extract], a copy of a writing-board [from? ...], ${ }^{71}$ [ta]bl[et] (of) Kișir-Aššur, son of Nabû-bē[ssunu the Assur exorcist/ exorcist of the Aššur temple], $7^{2}[\ldots]$ whose trust is [Na]bû, [T]ašmētu [...], 73 [son of B] aba-šuma-ibni, the zabardabbûu-priest of Ešarra; 74 [on oath of Nabû and Ma]rduk, do not [erase] my written name! 75 [...] Nabû and $\mathrm{M}\left[\right.$ arduk ... (curse?), ${ }^{76}$... $]$ him, and [...].

$B A K 200 \mathrm{~ms} \mathrm{~A}$

BAM 121 rev. 24: a-na șa-bat e-pe-še ZI-[h]a!

BAM 121 rev. 25: DUB-pi PZÚ.KEŠDA-AN.ŠÁR ša dPA NIR-su

BAM 121 rev. 26: DUMU p.dAG-be-sun lúMAŠ.MAŠ É AN.ŠÁR

Extracted for undertaking a (ritual) procedure, ${ }^{25}$ tablet of Kișir-Aššur, whose trust is Nabû, ${ }^{26}$ the son of Nabû-bēssunu, the exorcist of the Aššur temple.

$B A K 198 \mathrm{~ms} \mathrm{~B}$

$B A M 9$ is a "first [extract], a copy of a writing-board [from? ...]" and is designated as a tuppu of Kișir-Aššur. We should note that Kișir-Aššur's RA 15 pl. 76 and $R A$ 4O pl. 116, both copied as šamallû șehru and the former with the ša Nabû tuklassu addendum and described as "the 32nd? extract" copying a writing-board, were also designated as tuppus. This is not the case for KișirAššur's later numbered extracts. ${ }^{57}$

57 The catch-line of $B A M 9$ is repeated as the opening of the single prescription found on $B A M$ 145. This tablet's colophon is unfortunately too broken to determine who wrote it and for what purpose, although Scurlock remarks that "it is of the 'excerpted for specific performance' type" (Scurlock 2014: 423). Therefore, it is uncertain if we can regard this 
However, the ša Nabû tuklassu-phrase in BAM 9 does not resemble the way Kiṣir-Aššur ordinarily writes this phrase, as it also includes an uncertain passage concerning Tašmētu. ${ }^{58}$ Although this may be a variation, it is also noteworthy that the phrase occurs after Kișir-Aššur's father's name and in the middle of his geneology. No comparable examples can be identified among Kișir-Aššur's colophons. As such, it may be an elaborate praise of his father's devotion to the god of writing and his consort. Furthermore, the text contains a protective statement, and such statements only appear in the surviving evidence on tablets from Kișir-Aššur's šamallû șehru-, šamallû- and mašmaš büt $A \check{s ̌ s}$ ur-phases, as well as an uncertain phase (Section 6.2.3).

$B A M 121$ consists of one-line "ditto" (KI.MIN) prescriptions, ${ }^{59}$ it may have covered several physiological areas with changes marked with a double horizontal ruling, ${ }^{60}$ and it ends with a longer prescription on the reverse. Due to the ana șabāt epessi-phrase, however, the tablet was likely copied for the specific treatment of an afflicted patient, perhaps overseen by Kișir-Aššur himself (see Section 7.4). Furthermore, Kișir-Aššur used a logographic writing of his name in the colophon (Arbøll 2018b). This is one of only two surviving tablets from Kișir-Aššur in which this writing occurs (see also N4 no. 175). As such, it is unusual, although the content is not particularly unique.

\subsubsection{Kişir-Ǎš̌ur's Use of the ša Nabû tuklassu-phrase}

In general, the ša Nabû tuklassu-phrase in this form seems to occur mainly in connection with individuals connected to the $\mathrm{N}_{4}$ collection, such as the Bābašuma-ibni and Bēl-kundi-ilāya families (Borger 197ob: 167; cf. Hunger 1968: 12-15). ${ }^{61}$ A somewhat comparable phrase occurs in several of the colophons

tablet as the one Kiṣir-Aššur wrote following $B A M$ 9, although $B A M 145$ contains a number of erasures marked in Köcher's copy. See Ch. 3 note 38.

58 Cf. the following phrase in an Assurbanipal colophon on K. 9404 (Maul 1994: 540) rev. 3'-4': ša a-na A[N.Š] Á[R u Mullissu taklu ] 4' ša dAG ù d $T\left[a \check{s}-m e-t u_{4}\right.$ uznu rapaštu išrukūš $]$, "He who trusts in Aššur and Mullissu, onto whom Nabû and Tašmētu bestowed broad understanding" (Maul 1994: 28o, 282 ms C). See also Hunger 1968 no. 217, 237, 255, 319, $322-23,326,329-32,336,338,46$ o.

59 Obv. 4, 5, 6, 7, 13. See Section 3.2.

6o Obv. 1: DIS NA SAG [...], repeated in obv. 4, 5, 6, 7 and 8(?). Whether the initial diagnosis concerns the head (SAG.[DU]), headache (SAG.KI.DAB.BA), or the epigastrium (SAG ŠÀ) remains uncertain, but the focus was probably different to when it changes in obv. 9: DIŠ NA Gİ[RII-šú(?) ...], repeated in obv. 10, 12, 13 and rev. 14.

61 The Bēl-kundi-ilāya family's colophons can be found in $B A K 25^{2-54}, 5^{\circ} 4,508-10,518$ and 519 (Borger 1970b: 166; cf. Fadhil 2012: 41). Borger writes: "Die Floskel 'dessen Zuversicht Nabû ist' wird anscheinend nur in den Familien von Bel-Kundi-ilāya and vor Bāba-šumaibni ... gebraucht; Nr. 248 läßt sich freilich noch nicht auf diese Weise einordnen." (Borger 1970b: 167). $B A K$ no. 248 (= BAM 87 lines $25^{-26}$ ) reads: ${ }^{25}$ LIBIR.RA.BI.[GI]M AB.SAR 
from Assurbanipal's libraries. ${ }^{62}$ Maul interprets the ša Nabû tuklassu-phrase mainly as a pious and praising supplement, signalling that the copyist was a faithful trainee of Nabû, but without an exact function in $\mathrm{N}_{4}$ (Maul 2010a: 215 and note 96 ). Although he did not pursue his analysis further, the subordinate relationship to Nabû seems to occur most frequently diachronically within texts related to training (Gesche 2001: 159-61; Maul 1998: XII-XIV, XVI; Cavigneaux 1996: 24-27; Cavigneaux 1981: 37-38).

As shown by the šamallû șehru and šamallû mašmaššu șehru tablets on which this phrase occurs, it seems to be connected to a number of Kișir-Aššur's student tablets. This is corroborated comparatively by at least one commentary from Kișir-Nabû with this phrase ( $\mathrm{N}_{4}$ no. 163 = Geller 2014: 64ff.), albeit this text is from an unknown phase. A number of Kiṣir-Nabû's numbered extracts (BAM 52, BAM 106, BAM 147), of which two are instructional (BAM 52, BAM 106), also contain this phrase without a title. ${ }^{63}$ However, Kiṣir-Nabû's mašmaššuphase tablet $\mathrm{N}_{4}$ no. 247 likely also included the phrase, which argues against the above observations. ${ }^{64}$ The phrase may in Kișir-Aššur's case have been used primarily on apprentice phase tablets, although the evidence is far from conclusive.

Where does this place $B A M 9$ and $B A M$ 121? As argued in Section 7.1, titles were probably not omitted on tablets with names before Kișir-Aššur's later phases. The use of the ša Nabû tuklassu-phrase on these two tablets indicates they may have been part of Kișir-Aššur's apprentice phases. However, the phrase in $B A M 9$ may relate to Kiṣir-Aššur's father, Nabû-bēssunu, which would make this text the only example of such a use of the expression by Kișir-Aššur. This could indicate the text was earlier than other preserved texts with the $\check{s} a$ Nabû tuklassu-phrase. This observation, together with the fact that BAM 9 was a first extract related to the head, could support the text being from around Kișir-Aššur's šamallû șehru-phase. BAM 9 was also labelled a țuppu, much like the other numbered extract from his šamallû șehru-phase, $R A 15 \mathrm{pl}$. 76. KișirAššur's later extracts were not labelled as țppus. However, the evidence is

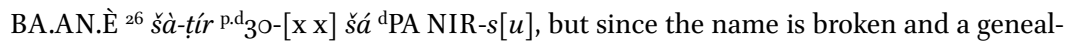
ogy is not mentioned, this text cannot be placed. However, it does originate from the $\mathrm{N}_{4}$ library (Pedersén 1986: 64 no. 188 = Ass. 13955/gz). The text $C T 15$ pl. 43f. published as $S A A$ 3 no. 37 is reconstructed by Livingstone (1989: 95) as Kișir-Nabû's on the basis of a partially visible [d $]^{\top} \mathrm{PA} \check{s} a{ }^{\mathrm{d}} \mathrm{AG}^{\top}$ tuk-lat-s[u]. However, the text was excavated in Nineveh and the relationship to Kișir-Nabû remains uncertain.

62 E.g., Hunger 1968: 98 lines 2-6.

63 Kișir-Aššur's texts also include numbered extracts from the mašmaš bìt Aššur-phase, thus these texts cannot be generalized according to training (Section 9.2.3).

$64 \mathrm{~N}_{4}$ no. 247 rev. 25: ú-il-ti P Ki-șir-dPA MAŠ.MAŠ ša [x x x (x)]. 
tenuous at best. Perhaps the lack of a title should be explained with this text being from before Kișir-Aššur officially became šamallû șehru.

$B A M 9$ contains a catch-line that opens the fragmentary tablet $B A M 145$ with a broken colophon (see Ch. 3 note 38 ). This text appears to be an exercise of some sort (Köcher 1963a: XII). If $B A M 145$ was copied by Kișir-Aššur after $B A M$ 9, this would further support $B A M 9$ as an earlier phase tablet. Considering the indications, although none are conclusive, I regard $B A M 9$ as a šamallû șehru tablet in this study.

$B A M 121$ contains a purpose statement, which indicates that this text is from a later phase of Kișir-Aššur's career (see Section 7.4). The combined use of the ša Nabû tuklassu-phrase together with a purpose statement may very tentatively indicate this was one of the first tablets Kiṣir-Aššur copied for a healing treatment. I suggest that the text may have been written slightly before or during the mašmaššu șehru-phase, in order to account for the ša Nabû tuklassuphrase combined with a purpose statement.

\section{$5 \cdot 5 \quad$ Summary}

The evidence for Kișir-Aššur's šamallû-, šamallû mašmaššu șehru- and mašmaššu șehru-phases is problematic as there are few texts, and the manuscripts in general probably cover several years of Kișir-Aššur's career. During his šamallû-phase, Kiṣir-Aššur copied incantations and brief ritual instructions for treating a "Curse" (māmitu), as well as guidelines for performing sections of the ritual bit mēseri. The latter text was copied "for his (own) 'reading", which suggests an instructive purpose. As a šamallû mašmǎ̌šu șehru, Kiṣir-Aššur copied texts connected to the domestic cult and infants. One ritual was aimed at reconciling a man with his god and another at treating ghosts, possibly related to the ancestral cult. Albeit very uncertain, Kișir-Aššur may have focused on such rituals to be able to treat possible causes of illness. Another of his šamallû mašmaššu șehru texts, an IM.GÍD.DA, attests to him copying a peculiar tradition of an incantation to calm an infant, baby or child. This focus on infants could be seen in relation to his other texts from this phase, as crying infants were known causes of disturbance for the family cult.

The incantation to calm an infant focused on Lamaštu, a known killer of infants and children. If Kișir-Aššur treated infants or children medically is uncertain. In general, such treatments are difficult to identify, and it is possible that adult treatments could be administered in revised versions to infants, babies or children. If so, Kișir-Aššur could have treated children, but this remains hypothetical. Nevertheless, there existed an overlap in physiological 
conceptualisation between infants and horses, which Kișir-Aššur had previously encountered as šamallû șehru. As a result, it is possible that he used this overlap to gain deeper insight into human physiology in order to provide better treatments. Due to the increasing economic and cultural worth of horses, children and adults, this chapter hypothesized that Kișir-Aššur may have experienced greater autonomy when aiding his father, first when treating horses, thereafter infants or children, and finally adults. If so, Kișir-Aššur would have been able to build upon previous insights into animal-human physiology. The argumentation follows the microhistoric approach seeking to illuminate the subject's world via comparative evidence to fill gaps in the documentation.

Kișir-Aššur was probably still training to become an exorcist during his mašmaššu șehru-phase, although the evidence is unclear (see Sections 5.3.1 and 6). His sole text from this phase consists of an u'iltu with two incantations and instructions. At least one of the incantations duplicates a relative simple spell used elsewhere for treating "Anus illness" (DÚR.GIG), which is ordinarily considered a relatively simple ailment (see Sections 3.1 and 3.1.1). The content of Kiṣir-Aššur's manuscript was described as "tested prescriptions, which are suitable for use(?)". In the surviving material, such statements were mainly employed after Kișir-Aššur became mašmaššu (see Sections 6.2.2 and 8.3; cf. Section 5.3). The text suggests that Kișir-Ǎšsur acquired certain treatments considered useful for practice during his mašmaššu șehru-phase. Comparative material from Kișir-Ǎšurur's nephew, Kișir-Nabû, indicates that initiation into advanced knowledge may have begun during the mašmaššu șehru. The fact that the material copied in Kișir-Aššur's sole text from this phase may have been used for treating "Anus illness", implies it may not have been considered advanced knowledge. Furthermore, his šamallû manuscript $\mathrm{N}_{4}$ no. 175 suggests that he began copying texts for gaining a deeper understanding of the content earlier during his training.

Concerning the differences in skill and responsibility that may be implied in the sequence of titles borne by Kișir-Ǎ̌šur before he became mašmaššu, a number of relevant observations have been presented throughout Chapters $3-5$. However, the publication of further texts assigned to Kișir-Aššur may alter individual observations as well as the importance of identified focuses. We may therefore not yet be in a position to fully understand all aspects of KișirǍšur's training. Nonetheless, I have argued extensively for my ideas, which are supported by comparative evidence. Thus, I consider the hypothesised progression in patient groups, defined by a social hierarchy and autonomous practice, a likely scenario. Although he copied numerous medical texts with treatments for adults, I have on the basis of thorough discussions proposed that some material could perhaps be modified and applied to animals and 
children as well (Section 5.2.2). Furthermore, I have argued that he likely aided his father simultaneously in treating adults and preparing healing ceremonies during his training.

Alternative hypotheses may be suggested, although a progression from simple to complex material is not reflected in the material. Almost all of KișirAššur's šamallû șehru manuscripts concern healing or rituals instructions for a single individual. During his šamallû-phase, he copied two rituals related to the individual and his house. As a šamallû mašmaššu șehru, Kișir-Aššur copied texts connected to the domestic cult and infants. When he became mašmaššu șehru, he learned tested healing procedures. As a mašmaššu, he copied an increasing number of different text types relevant to practice (Chapter 6), and a wide variety of rituals were copied during this and his mašmaš bit Aššurphase (Chapter 8). Thus, a tentative progress from individual to household in terms of illness, and finally a change in focus towards social problems, evil omens and official cult can be proposed. 